\title{
Design Verification and Acceptance Tests of the ASST-A Helium Refrigeration System *
}

\author{
V. Ganni and T. Apparao \\ Superconducting Super Collider Laboratory ${ }^{\dagger}$ \\ 2550 Beckleymeade Ave. \\ Dallas, TX 75237
}

July 1993

"Presented at the International Cryogenics Engineering Conference, July 12-14, Albuquerque, N.M.

${ }^{+}$Operated by the Universities Research Association, Inc., for the U.S. Department of Energy under Contract No. DE-AC35-89ER40486. 


\title{
DESIGN VERIFICATION AND ACCEPTANCE TESTS OF THE ASST-A HELIUM REFRIGERATION SYSTEM
}

\author{
V. Ganni and T. V. V. R. Apparao \\ Cryogenics Department, Accelerator Systems Division \\ Superconducting Super Collider Laboratory* \\ Dallas, TX 75237
}

\section{INTRODUCTION}

Three similar helium refrigerator systems have been installed at the Superconducting Super Collider Laboratory (SSCL) N15 site: the ASST-A system, which will be used for the accelerator system's full cell string test; the N15-B system, which will be used for string testing in the tunnel; and a third plant, dedicated to magnet testing at the Magnet Testing Laboratory. The ASST-A and N15-B systems will ultimately be a part of the collider's N15 sector station equipment. Each of these three systems has many subsystems, but the design basis for the main refrigerator is the same and is given in Reference 1. The flow diagram of the ASST-A system, the subject of this report, is shown in Figure 1. Each system has a guaranteed capacity of $2000 \mathrm{~W}$ of refrigeration and $20 \mathrm{~g} / \mathrm{s}$ liquefaction at $4.5 \mathrm{~K}$.

The testing and design verification of the ASST-A refrigeration system consisted of parametric tests on the compressors and the total system. A summary of the initial performance test data is given in Reference 2. The tests were conducted for two cases: in the first (Case 1), all four compressors were operating; in the second (Case 2), only one compressor in each stage was operating. In each case, tests were conducted in three modes of operation described later on.

The process design basis supplied by the manufacturers and used in the design of the main components-the compressor, and expanders and heat exchangers for the coldboxwere used to reduce the actual test data using process simulation methodology. In addition, the test results and the process design submitted by the manufacturer were analyzed using exergy analysis. This paper presents both the process and the exergy analyses of the manufacturer's design and the actual test data for Case 1. The process analyses are presented in the form of T-S diagrams. The results of the exergy analyses comparing the exergy losses of each component and the total system for the manufacturer's design and the test data are presented in the tables.

\footnotetext{
* Operated by the Universities Research Assaiation, Inc., for the U. S. Department of Energy under Contract No DE-AC35-89ER40480.
} 


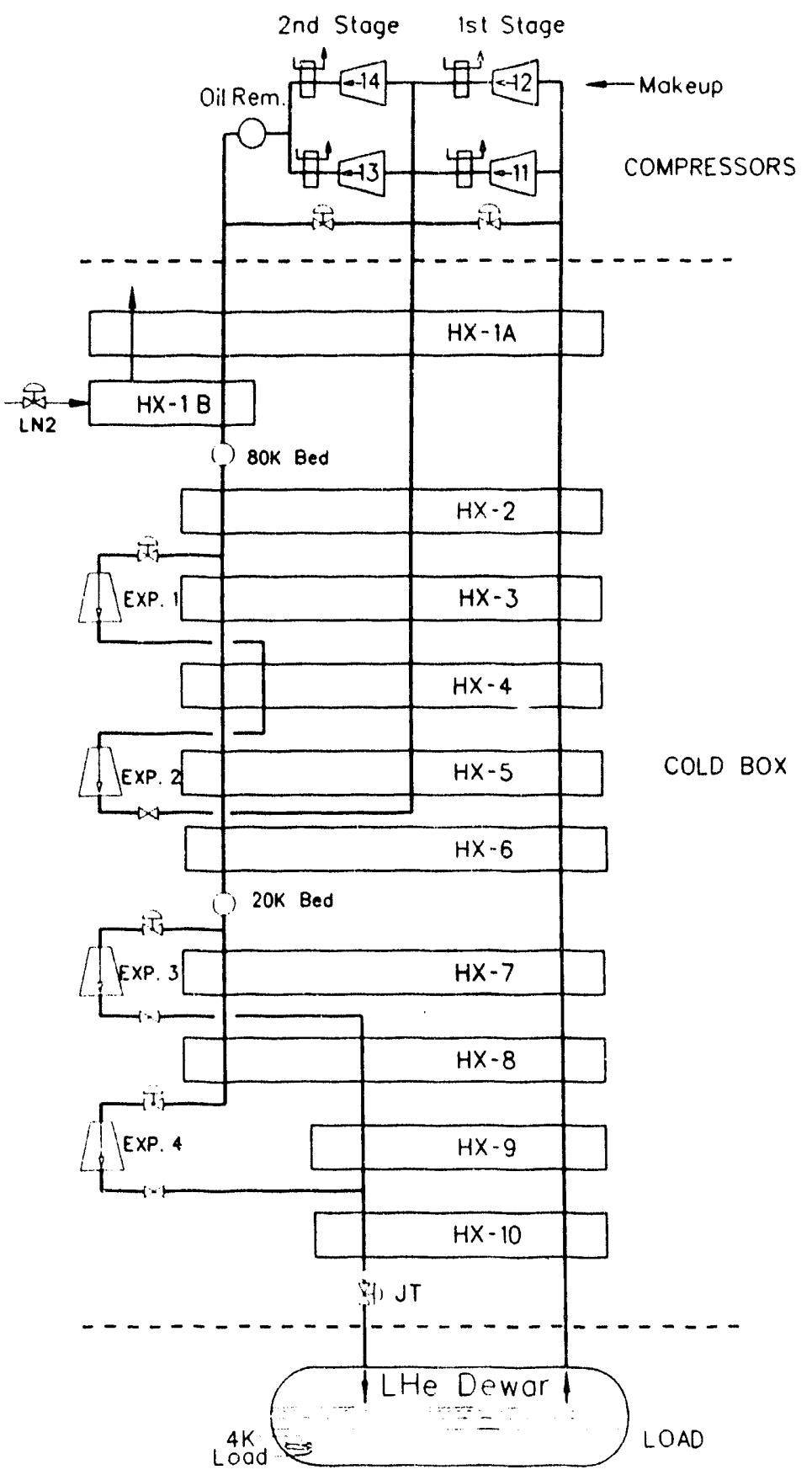

Figure 1. Refrigeration system flow diagram.

\section{COMPRESSOR SYSTEM}

The compressor system consists of two first-stage and two second-stage Sullair screw compressors. Prior to the total system test, parametric tests were conducted to map each compressor. The volumetric and isothermal efficiencies (the latter include the motor efficiency) for one first-stage and one second-stage compressor are given in Figure 2. The efficiency values provided by the manufacturer (Sullair) and used in the design are shown in Figure 2, as are the efficiency values reduced from the test data for the three modes. 

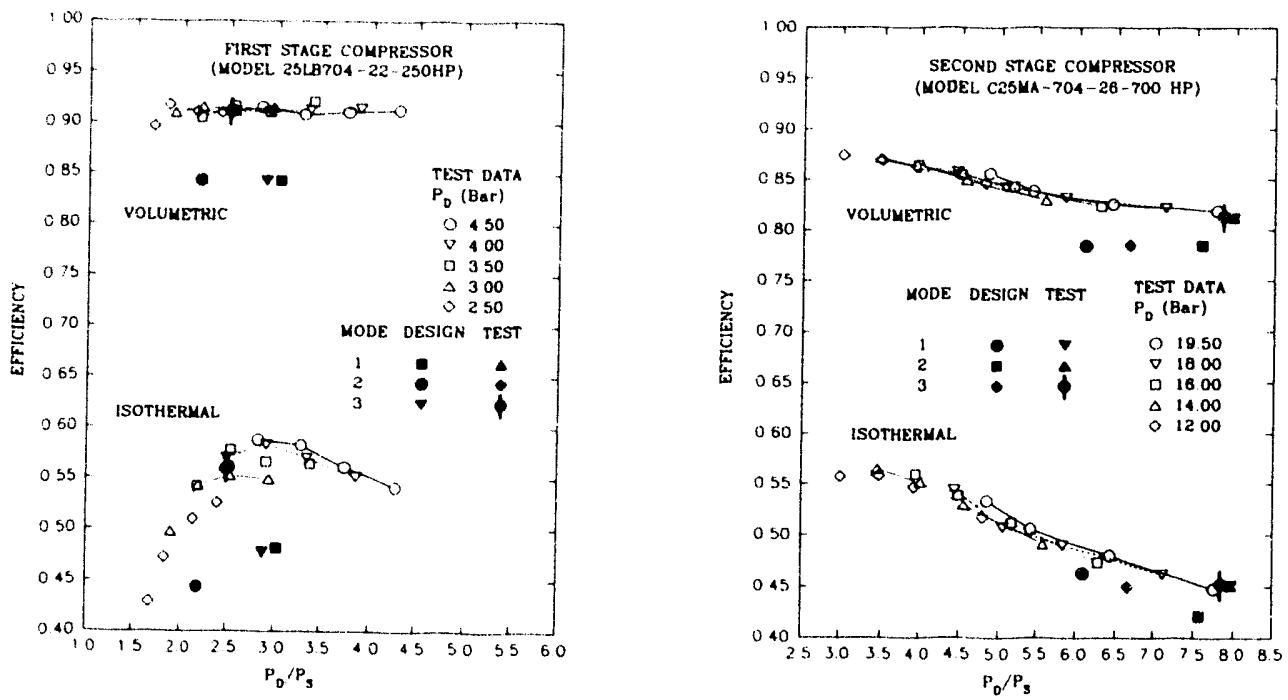

Figure 2. Compressor characteristics.

\section{COLDBOX SYSTEM .}

The coldbox contains 11 heat exchangers grouped into six brazed aluminum cores, housed together with four expanders, two $80-\mathrm{K}$ beds, one $20-\mathrm{K}$ bed, and associated valves, piping, and instrumentation. For comparison of the manufacturer's design with test data of the processes for the three modes, see Figures 3-5.

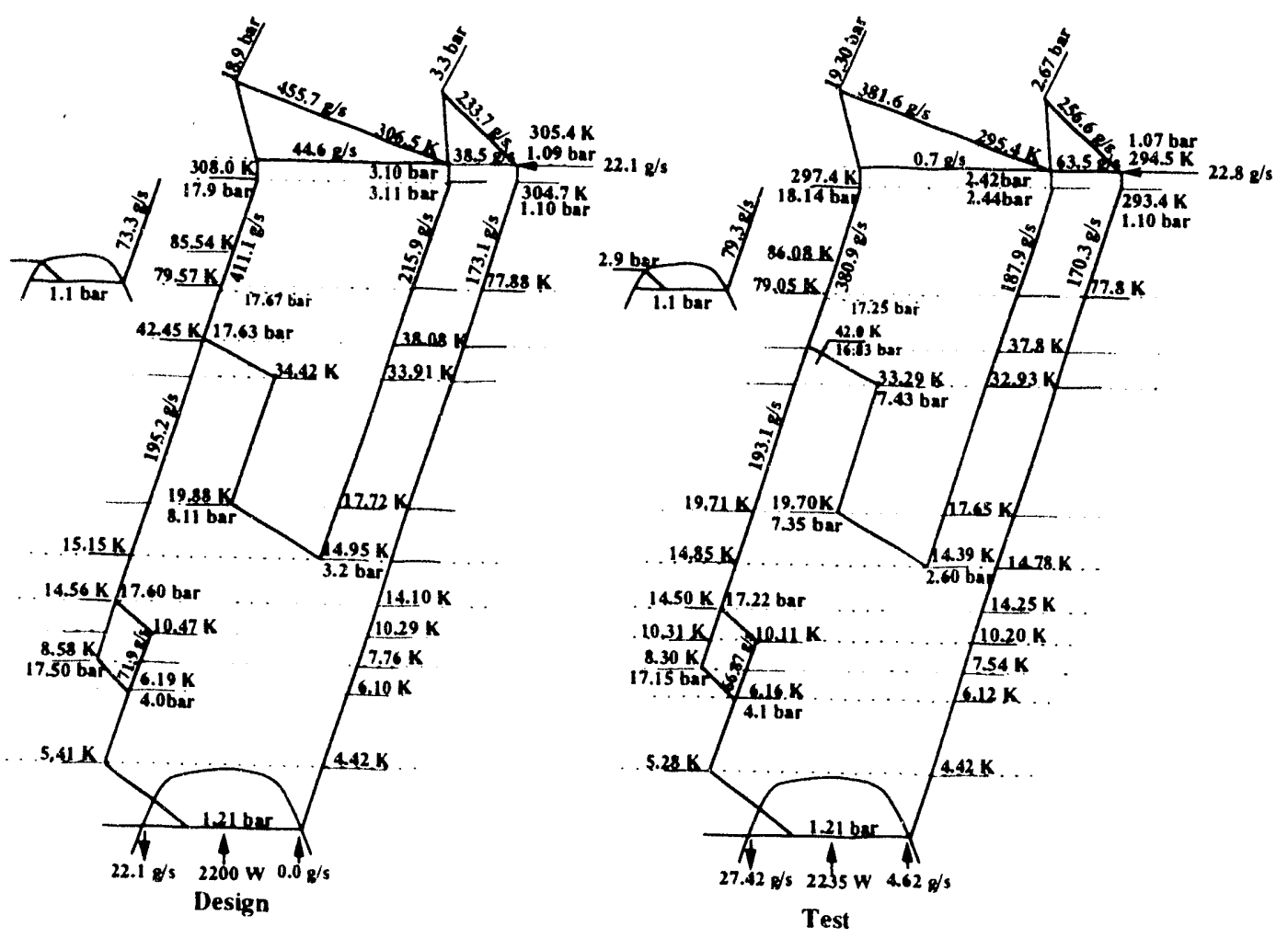

Figure 3. Mode 1 (50L-50R) process analysis (110\% of guaranteed capacity). 


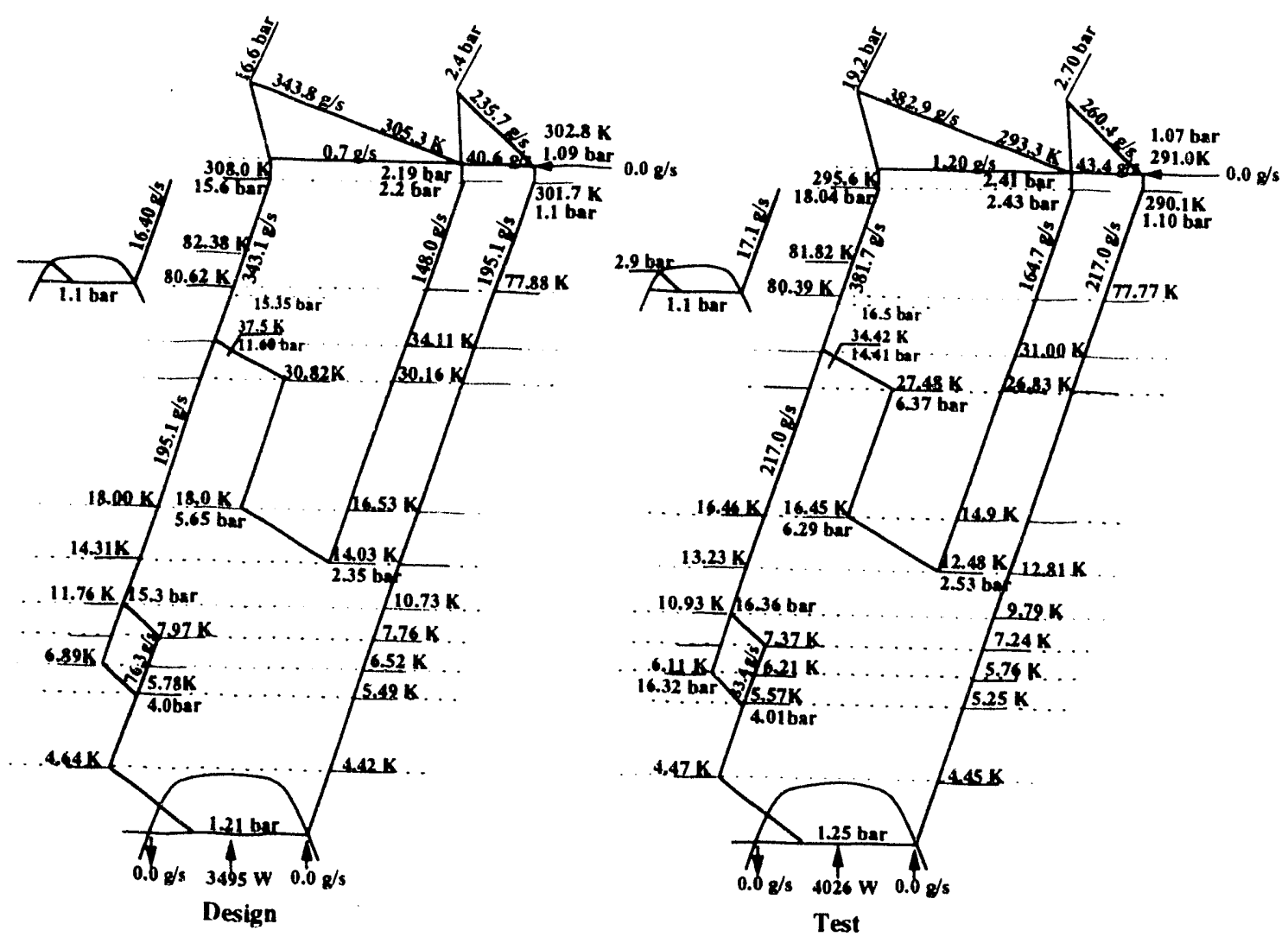

Figure 4. Mode 2 (100R) process analysis.

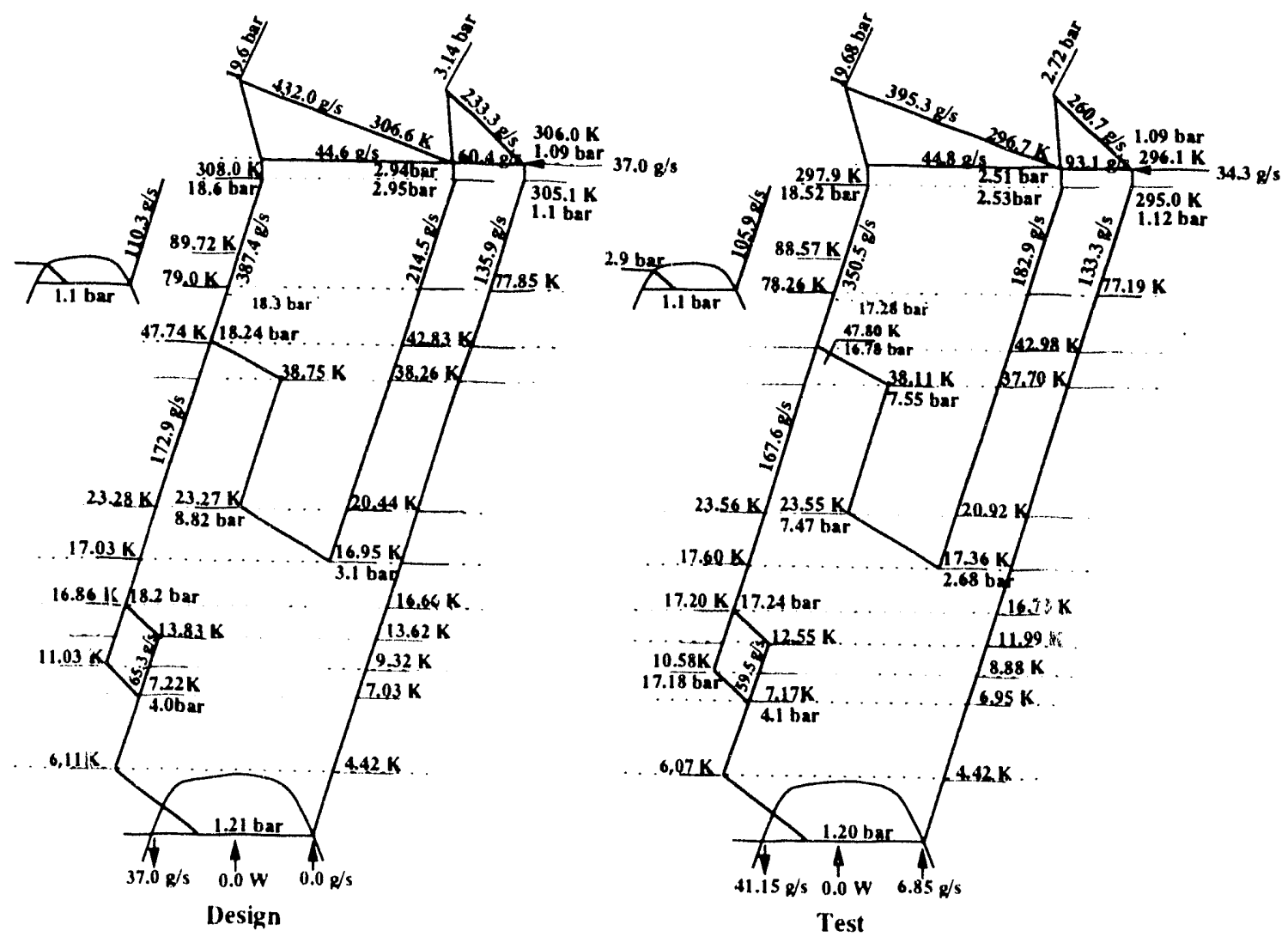

Figure 5. Mode 3 (100L) process analysis. 


\section{LOAD}

The refrigeration load is applied in the 40,000-L liquid helium dewar with electric heaters. The liquefaction rate is measured by makeup gas and is verified with the depletion of the helium gas from the gas tanks and observation of the accumulated liquid in the dewar.

\section{THEORY}

The process analysis was performed using the characteristics of the subcomponents of the system supplied by the manufacturers. The present work uses the theory of exergy analysis as applied to refrigeration systems. ${ }^{3}$ The theory shows the importance of irreversibilities and how to minimize them. It shows the importance of $d t / t$ and $d p / p$ parameters in designing these systems. The maximum available specific work function or exergy is defined as:

$$
d e=d h-t_{0} \times d s
$$
where $e$ is exergy $(\mathrm{j} / \mathrm{g}), h$ is enthalpy $(\mathrm{j} / \mathrm{g}), t_{o}$ is sink temperature $(\mathrm{K})$, and $s$ is entropy
$(\mathrm{j} / \mathrm{g}-\mathrm{K})$.

An example of application of this theory to helium systems is given in Reference 4.

\section{TEST MODES OF THE SYSTEM}

Preliminary tests were conducted to ascertain that the system has the guaranteed capacity, and no attempt was made to find the maximum capacity or the efficiency of the system so long as it exceeded the guaranteed capacity and operated close to the design basis. During the process simulations, small adjustments were made to the test data when they did not satisfy the mass and energy balances and/or the expander flow characteristics, to compensate for instrument resolution and accuracy limitations and errors. In some modes of operation, additional cooling occurred in the outdoor oil removal system due to low ambient temperature, and therefore the cooling water temperature was not used as the sink temperature, $t_{0}$. Instead, $t_{0}$ was assumed to be the average of the coldbox warm end inlet and outlet temperatures for the process analysis and exergy calculations.

For the compressor system, the exergy losses due to motor inefficiencies, non-ideal compression, and the cooling provided in the aftercooler and oil cooler are treated as a single loss. The exergy loss due to the pressure drop across the first-stage aftercooler and the second-stage aftercooler and oil removal system are treated separately to show the pressure drop effect on the system input power.

In the coldbox, the losses are: (1) the heat exchangers, whose losses are due to temperature differences, $d t$, between streams and heat leak; (2) the expanders, whose losses are due to the inefficiencies in expansion and wasted expander output; and (3) miscellaneous losses, which include nitrogen system losses, pressure drops, JT expansion, and heat leaks. During testing, there was an approximately l-bar pressure drop across the 80-K adsorber bed filter. Tests were conducted with this pressure drop and modifications to the filter are under way to reduce it. The exergy analysis shows the effect of this pressure drop on the input
power.

\section{Mode 1 (50L-50R)}

This mode is the system design basis. In this mode the system is required to produce $2000 \mathrm{~W}$ of refrigeration and $20 \mathrm{~g} / \mathrm{s}$ of liquefaction at $4.5 \mathrm{~K}$-approximately $50 \%$ liquefaction and $50 \%$ refrigeration load on the exergy basis. The system is designed with a $10 \%$ margin. 
Figure 3 and Table 1 compare the results of manufacturer's design with the actual test data for this mode of operation.

\section{Mode 2 (100R)}

In this mode all the available system capacity is used for $4.5-\mathrm{K}$ refrigeration. The expected design refrigeration capacity is given as $3495 \mathrm{~W}$ and the system was tested at $4025 \mathrm{~W}$. The higher capacity was achieved, due primarily to the compressors having higher than assumed volumetric efficiency and available motor capacity, resulting in higher discharge pressure and flow. Figure 4 and Table 2 compare the results of the manufacturer's design with the actual test data.

\section{Mode 3 (100L)}

In this mode all the available system capacity is used for liquefaction. The expected design liquefaction capacity is given as $37 \mathrm{~g} / \mathrm{s}$ and the system was tested at $34.3 \mathrm{~g} / \mathrm{s}$. The system is expected to produce the predicted capacity once the $80-\mathrm{K}$ bed filter pressure drop is minimized and the second-stage compressor is operated at a lower suction pressure to minimize the bypass flow. Figure 5 shows the process analysis and Table 3 provides the exergy analysis for this mode. 
Table 1. Mode 1 (50L-50R) exergy analysis.

\begin{tabular}{|c|c|c|c|c|}
\hline & \multicolumn{2}{|c|}{ DESIGN } & \multicolumn{2}{|c|}{ TEST } \\
\hline $4.5 \mathrm{~K}$ Refrigeration load (W) & \multicolumn{2}{|c|}{2200.0} & \multicolumn{2}{|c|}{2235.0} \\
\hline Liquefaction load $(\mathrm{g} / \mathrm{s})$ & \multicolumn{2}{|c|}{22.1} & \multicolumn{2}{|c|}{22.8} \\
\hline Reliquefaction load $(\mathrm{g} / \mathrm{s})$ & \multirow{2}{*}{\multicolumn{2}{|c|}{$\frac{0.0}{306.4}$}} & \multicolumn{2}{|c|}{4.62} \\
\hline Coolant reference temperature $(\mathrm{K})$ & & 306.4 & \multicolumn{2}{|c|}{295.4} \\
\hline INPUT & $\mathbf{k W}$ & $\%$ & $\mathbf{k W}$ & $\%$ \\
\hline First-Stage Compressor & 340.6 & 20.9 & 257.1 & 17.2 \\
\hline Second-Stage Compressor & 1132.3 & 69.7 & 1078.5 & 72.3 \\
\hline $\mathrm{LN}_{2}$ System (Eff. Carnot $=0.35$ ) & 152.6 & 9.4 & 156.9 & 10.5 \\
\hline INPUT EXERGY TOTAL & 1625.5 & 100.0 & 1492.5 & 100.0 \\
\hline OUTPUT & $\mathbf{k W}$ & $\%$ & $\mathbf{k W}$ & $\%$ \\
\hline First-stage: compressor and motor & 176.3 & 10.8 & 113.0 & 7.6 \\
\hline First-stage bypass & 26.6 & 1.6 & 34.2 & 2.3 \\
\hline First-stage suction mixing & 4.7 & 0.3 & 7.7 & 0.5 \\
\hline First-stage aftercooler DP & 7.4 & 0.5 & 13.4 & 0.9 \\
\hline First-stage subtotal & 214.9 & 13.2 & 168.3 & 11.3 \\
\hline Second-stage compressor and motor & 607.9 & 37.4 & 592.0 & 39.7 \\
\hline Second-stage bypass & 51.0 & 3.1 & 0.8 & 0.1 \\
\hline Second-stage suction mixing & 4.4 & 0.3 & 4.0 & 0.3 \\
\hline Second-stage AC and oil rem. DP & 11.9 & 0.7 & 11.6 & 0.8 \\
\hline Second-stage subtotal & 675.3 & 41.5 & 608.4 & 40.8 \\
\hline COMPRESSORS - SUBTOTAL & 890.2 & 54.8 & 776.7 & 52.0 \\
\hline Heat exchanger $1 \mathrm{~A}$ & 47.1 & 2.9 & 47.3 & 3.2 \\
\hline Heat exchanger $1 \mathrm{~B}$ & 6.5 & 0.4 & 6.3 & 0.4 \\
\hline Heat exchanger 2 & 26.4 & 1.6 & 22.3 & 1.5 \\
\hline Heat exchanger 3 & 4.7 & 0.3 & 4.4 & 0.3 \\
\hline Heat exchanger 4 & 23.0 & 1.4 & 19.1 & 1.3 \\
\hline Heat exchanger 5 & 7.0 & 0.4 & 7.1 & 0.5 \\
\hline Heat exchanger 6 & 0.9 & 0.1 & 0.6 & 0.0 \\
\hline Heat exchanger 7 & 2.4 & 0.1 & 1.5 & 0.1 \\
\hline Heat exchanger 8 & 5.6 & 0.3 & 5.0 & 0.3 \\
\hline Heat exchanger 9 & 2.3 & 0.1 & 2.2 & 0.1 \\
\hline Heat exchanger 10 & 20.3 & 1.2 & 18.9 & 1.3 \\
\hline Heat exchangers - subtotal & 146.2 & 9.0 & 134.7 & 9.0 \\
\hline Expander 1 & 35.4 & 2.2 & 28.0 & 1.9 \\
\hline Expander 2 & 33.4 & 2.1 & 32.3 & 2.2 \\
\hline Expander 3 & 37.7 & 2.3 & 27.0 & 1.8 \\
\hline Expander 4 & 29.5 & 1.8 & 26.5 & 1.8 \\
\hline Expanders - subtotal & 135.9 & 8.4 & 113.8 & 7.6 \\
\hline $\mathrm{LN}_{2}$ system & 99.6 & 6.1 & 102.4 & 6.9 \\
\hline $80-K$ bed & 0.5 & 0.0 & 10.6 & 0.7 \\
\hline DP I/O expanders & 0.1 & 0.0 & 3.0 & 0.2 \\
\hline JT & 37.5 & 2.3 & 33.9 & 2.3 \\
\hline Transfer line & 3.5 & 0.2 & 3.4 & 0.2 \\
\hline Dewar heat leak & 0.0 & 0.0 & 0.7 & 0.0 \\
\hline Calculation error & 9.6 & 0.6 & 10.1 & 0.7 \\
\hline Miscellaneous - subtotal & 150.8 & 9.3 & 164.0 & 11.0 \\
\hline COLDBOX - SUBTOTAL & 433.0 & 26.6 & 412.5 & 27.6 \\
\hline EXERGY LOSS - TOTAL & 1323.2 & 81.4 & 1189.3 & 79.7 \\
\hline Refrigeration load & 149.9 & 9.2 & 146.9 & 9.8 \\
\hline Liquefaction load & 152.4 & 9.4 & 150.4 & 10.1 \\
\hline Reliquefaction load & 0.0 & 0.0 & 5.9 & 0.4 \\
\hline EXERGY USEFUL - TOTAL & 302.3 & 18.6 & 303.3 & 20.3 \\
\hline OUTPUT EXERGY TOTAL & 1625.5 & 100.0 & 1492.5 & 100.0 \\
\hline
\end{tabular}


Table 2. Mode 2 (100R) exergy analysis.

\begin{tabular}{|c|c|c|c|c|}
\hline & \multirow{2}{*}{\multicolumn{2}{|c|}{$\frac{\text { DESIGN }}{3495.0}$}} & \multicolumn{2}{|c|}{ TEST } \\
\hline $4.5 \mathrm{~K}$ Refrigeration load (W) & & & & \\
\hline Liquefaction load $(\mathrm{g} / \mathrm{s})$ & \multicolumn{2}{|c|}{0.0} & \multicolumn{2}{|c|}{0.0} \\
\hline Reliquefaction load $(\mathrm{g} / \mathrm{s})$ & \multirow{2}{*}{\multicolumn{2}{|c|}{$\frac{0.0}{304.9}$}} & \multicolumn{2}{|c|}{0.0} \\
\hline Coolant reference temperature $(\mathrm{K})$ & & & & \\
\hline INPUT & $\mathbf{k W}$ & $\%$ & $\mathbf{k W}$ & $\%$ \\
\hline First-Stage Compressor & 262.1 & 19.5 & 259.6 & 19.0 \\
\hline Second-Stage Compressor & 1046.1 & 77.8 & 1073.5 & 78.6 \\
\hline LN2 System (Eff. Carnot $=0.35$ ) & 36.4 & 2.7 & 33.2 & 2.4 \\
\hline INPUT EXERGY TOTAL & 1344.6 & 100.0 & 1366.3 & 100.0 \\
\hline OUTPUT & kW & $\%$ & $\mathbf{k W}$ & $\%$ \\
\hline First-stage: compressor and motor & 145.6 & 10.8 & 113.8 & 8.3 \\
\hline First-stage bypass & 19.6 & 1.5 & 23.4 & 1.7 \\
\hline First-stage suction mixing & 3.3 & 0.2 & 6.5 & 0.5 \\
\hline First-stage aftercooler DP & 11.1 & 0.8 & 15.9 & 1.2 \\
\hline First-stage subtotal & 179.6 & 13.4 & 159.6 & 11.7 \\
\hline Second-stage compressor and motor & 606.8 & 45.1 & 591.2 & 43.3 \\
\hline Second-stage bypass & 0.9 & 0.1 & 1.5 & 0.1 \\
\hline Second-stage suction mixing & 3.3 & 0.2 & 3.9 & 0.3 \\
\hline Second-stage AC and oil rem. DP & 10.6 & 0.8 & 11.6 & 0.8 \\
\hline Second-stage subtotal & 621.6 & 46.2 & 608.2 & 44.5 \\
\hline COMPRESSORS - SUBTOTAL & 801.2 & 59.6 & 767.7 & 56.2 \\
\hline Heat exchanger $1 \mathrm{~A}$ & 35.8 & 2.7 & 37.4 & 2.7 \\
\hline Heat exchanger $1 \mathrm{~B}$ & 3.6 & 0.3 & 3.9 & 0.3 \\
\hline Heat exchanger 2 & 26.7 & 2.0 & 28.6 & 2.1 \\
\hline Heat exchanger 3 & 5.7 & 0.4 & 5.6 & 0.4 \\
\hline Heat exchanger 4 & 15.8 & 1.2 & 20.1 & 1.5 \\
\hline Heat exchanger 5 & 4.8 & 0.4 & 9.0 & 0.7 \\
\hline Heat exchanger 6 & 5.0 & 0.4 & 7.1 & 0.5 \\
\hline Heat exchanger 7 & 7.7 & 0.6 & 9.7 & 0.7 \\
\hline Heat exchanger 8 & 2.3 & 0.2 & 3.6 & 0.3 \\
\hline Heai exchanger 9 & 3.8 & 0.3 & 4.6 & 0.3 \\
\hline Heat exchanger 10 & 11.1 & 0.8 & 7.0 & 0.5 \\
\hline Heat exchangers - subtotal & 122.2 & 9.1 & 136.5 & 10.0 \\
\hline Expander 1 & 21.9 & 1.6 & 26.4 & 1.9 \\
\hline Expander 2 & 26.2 & 2.0 & 25.1 & 1.8 \\
\hline Expander 3 & 23.0 & 1.7 & 24.8 & 1.8 \\
\hline Expander 4 & 2.2 .8 & 1.7 & 25.7 & 1.9 \\
\hline Expanders - subtotal & 94.0 & 7.0 & 102.1 & 7.5 \\
\hline LN2 system & 23.7 & 1.8 & 21.7 & 1.6 \\
\hline $80-\mathrm{K}$ bed & 0.5 & 0.0 & 19.0 & 1.4 \\
\hline DP I/O expanders & 27.2 & 2.0 & 19.7 & 1.4 \\
\hline $\mathrm{JT}$ & 29.5 & 2.2 & 30.8 & 2.3 \\
\hline Transfer line & 3.5 & 0.3 & 3.3 & 0.2 \\
\hline Dewar heat leak & 0.0 & 0.0 & 0.6 & 0.0 \\
\hline Calculation error & 5.9 & 0.4 & 4.7 & 0.3 \\
\hline Miscellaneous - subtotal & 90.2 & 6.7 & 99.9 & 7.3 \\
\hline COLDBOX - SUBTOTAL & 306.4 & 22.8 & $\mathbf{3 3 8 . 5}$ & 24.8 \\
\hline EXERGY LOSS - TOTAL & 1107.7 & 82.4 & 1106.2 & 81.0 \\
\hline Refrigeration load & 236.9 & 17.6 & 260.1 & 19.0 \\
\hline Liquefaction load & -0.0 & 0.0 & 0.0 & 0.0 \\
\hline Reliquefaction load & 0.0 & 0.0 & 0.0 & 0.0 \\
\hline EXERGY USEFUL - TOTAL & 236.9 & 17.6 & 260.1 & 19.0 \\
\hline OUTPUT EXERGY TOTAL & 1344.6 & 100.0 & 1366.3 & 100.0 \\
\hline
\end{tabular}


Table 3. Mode 3 (100L) exergy analysis.

\begin{tabular}{|c|c|c|c|c|}
\hline & \multirow{2}{*}{\multicolumn{2}{|c|}{$\frac{\text { DESIGN }}{0.0}$}} & \multicolumn{2}{|c|}{ TEST } \\
\hline $4.5 \mathrm{~K}$ Refrigeration load $(\mathrm{W})$ & & & \multirow{2}{*}{\multicolumn{2}{|c|}{$\frac{0.0}{34.3}$}} \\
\hline Liquefaction load $(\mathrm{g} / \mathrm{s})$ & \multicolumn{2}{|c|}{37.0} & & \\
\hline Reliquefaction load (g/s) & \multicolumn{2}{|c|}{$\frac{0.0}{306.6}$} & \multicolumn{2}{|c|}{6.85} \\
\hline Coolant reference temperature $(\mathrm{K})$ & \multicolumn{2}{|c|}{306.6} & \multicolumn{2}{|c|}{296.4} \\
\hline INPUT & $\mathbf{k W}$ & $\%$ & $\mathbf{k W}$ & $\%$ \\
\hline First-Stage Compressor & 328.1 & 18.9 & 262.0 & 16.6 \\
\hline Second-Stage Compressor & 1159.5 & 66.8 & 1108.1 & 70.0 \\
\hline $\mathrm{LN}_{2}$ System (Eff. Carnot $=0.35$ ) & 247.7 & 14.3 & 212.3 & 13.4 \\
\hline INPUT EXERGY TOTAL & 1735.3 & 100.0 & 1582.4 & 100.0 \\
\hline OUTPUT & $\mathbf{k W}$ & $\%$ & $\mathbf{k W}$ & $\%$ \\
\hline First-stage: compressor and motor & 171.1 & 9.9 & 115.3 & 7.3 \\
\hline First-stage bypass & 39.8 & 2.3 & 50.1 & 3.2 \\
\hline First-stage suction mixing & 5.6 & 0.3 & 8.9 & 0.6 \\
\hline First-stage aftercooler DP & 7.8 & 0.5 & 10.8 & 0.7 \\
\hline First-stage subtotal & 224.3 & 12.9 & 185.1 & 11.7 \\
\hline Second-stage compressor and motor & 636.8 & 36.7 & 605.3 & 38.3 \\
\hline Second-stage bypass & 53.6 & 3.1 & 56.4 & 3.6 \\
\hline Second-stage suction mixing & 4.2 & 0.2 & 4.3 & 0.3 \\
\hline Second-stage AC and oil rem. DP & 10.8 & 0.6 & 11.7 & 0.7 \\
\hline Second-stage subtotal & 705.3 & 40.6 & 677.8 & 42.8 \\
\hline COMPRESSORS - SUBTOTAL & 929.7 & 53.6 & 862.9 & 54.5 \\
\hline Heat exchanger 1A & 61.0 & 3.5 & 47.3 & 3.0 \\
\hline Heat exchanger 1B & 9.9 & 0.6 & 8.4 & 0.5 \\
\hline Heat exchanger 2 & 19.3 & 1.1 & 15.7 & 1.0 \\
\hline Heat exchanger 3 & 4.1 & 0.2 & 3.8 & 0.2 \\
\hline Heat exchanger 4 & 22.1 & 1.3 & 17.6 & 1.1 \\
\hline Heal exchanger 5 & 7.3 & 0.4 & 6.3 & 0.4 \\
\hline Heat exchanger 6 & 0.4 & 0.0 & 0.3 & 0.0 \\
\hline Heat exchanger 7 & 0.6 & 0.0 & 2.4 & 0.2 \\
\hline Heat exchanger 8 & 7.4 & 0.4 & 7.1 & 0.4 \\
\hline Heat exchanger 9 & 5.3 & 0.3 & 5.0 & 0.3 \\
\hline Heat exchanger 10 & 21.9 & 1.3 & 22.7 & 1.4 \\
\hline Heat exchangers - subtotal & 159.5 & 9.2 & 136.7 & 8.6 \\
\hline Expander 1 & 28.5 & 1.6 & 26.6 & 1.7 \\
\hline Expander 2 & 37.4 & 2.2 & 31.5 & 2.0 \\
\hline Expander 3 & 49.6 & 2.9 & 27.5 & 1.7 \\
\hline Expander 4 & 35.2 & 2.0 & 33.2 & 2.1 \\
\hline Expanders - subtotal & 150.6 & 8.7 & 118.8 & 7.5 \\
\hline LN2 system & 161.0 & 9.3 & 138.5 & 8.8 \\
\hline $80-\mathrm{K}$ bed & 0.6 & 0.0 & 14.0 & 0.9 \\
\hline DP I/O expanders & 0.1 & 0.0 & 3.5 & 0.2 \\
\hline $\mathrm{JT}$ & 62.3 & 3.6 & 57.1 & 3.6 \\
\hline Transfer line & 3.5 & 0.2 & 3.4 & 0.2 \\
\hline Dewar heat leak & 0.0 & 0.0 & 0.7 & 0.0 \\
\hline Calculation error & 12.6 & 0.7 & 10.9 & 0.7 \\
\hline Miscellaneous - subtotal & 240.1 & 13.8 & 228.1 & 14.4 \\
\hline COLDBOX - SUBTOTAL & 550.2 & 31.7 & 483.6 & 30.6 \\
\hline EXERGY LOSS - TOTAL & 1479.8 & 85.3 & 1346.5 & 85.1 \\
\hline Refrigeration Load & 0.0 & 0.0 & 0.0 & 0.0 \\
\hline Liquefaction L oad & 255.4 & 14.7 & 227.0 & 14.3 \\
\hline Reliquefaction load & 0.0 & 0.0 & 8.9 & 0.6 \\
\hline EXERGY USEFUL - TOTAL & 255.4 & 14.7 & 235.9 & 14.9 \\
\hline OUTPUT EXERGY TOTAL & 1735.3 & 100.0 & 1582.4 & 100.0 \\
\hline
\end{tabular}




\section{DISCUSSION AND CONCLUSIONS}

The refrigeration system was designed to be $50 \%$ refrigerator and $50 \%$ liquefier and should operate over a wide range of load conditions from $100 \%$ refrigeration to $100 \%$ liquefaction. The process and exergy analyses are useful tools for comparing the system behavior and performance at design and off-design conditions.

The detailed exergy analyses presented in Tables 1-3 and in Figure 6 show that the miscellaneous losses and compressor bypass flow losses are a smaller fraction in the refrigeration mode than in the liquefaction mode. In the liquefaction mode nitrogen precooling dominates the miscellaneous losses. Some capacity can be gained by operating the second stage at a lower suction pressure, thereby reducing the bypass flow losses. During the tests conducted subsequently, the system was operated with a low setpoint $(2.2$ bar $)$ for the second-stage compressor suction. Depending on the mode, this minimized or eliminated the second-stage bypass flow. The system behavior was very stable over a wide range of load levels, for all types of load-refrigeration, liquefaction, and mixed. The system pressure levels adjusted automatically to match the load and thus minimized the input power. Controlled measurements will be made in the future with this self-adjusting control system in place, to find the system maximum capacity and efficiency. Operating the system in some modes at a higher-than-design second-stage pressure ratio and discharge pressure resulted in higher capacities; however, this resulted in reduced isothermal efficiencies.

Exergy analysis is a very strong tool for explaining how input energy is used by the individual components and by the load. Energy optimization involves minimization of input power for a required output power, and the normal question raised is: What is the economic optimum for the components in the system? The process industry uses a constant for the ratio of monetary value per unit of input power (e.g., $\$ 1000 / \mathrm{kW}$ ). This constant is difficult to apply to the individual components. The exergy loss analysis can readily be applied for the economic optimization of each component and its effect on the total system. As an example, the first-stage aftercooler pressure drop $(\sim 0.3$ bar $)$ uses approximately the same amount of energy as the combined pressure drops across the second-stage aftercooler and the oil removal system $(\sim 1 \mathrm{bar})$. This is because the sum of the products of the mass flow and the $\mathrm{dp} / \mathrm{p}$ for each of these latter items is approximateiy equal to that of the former.

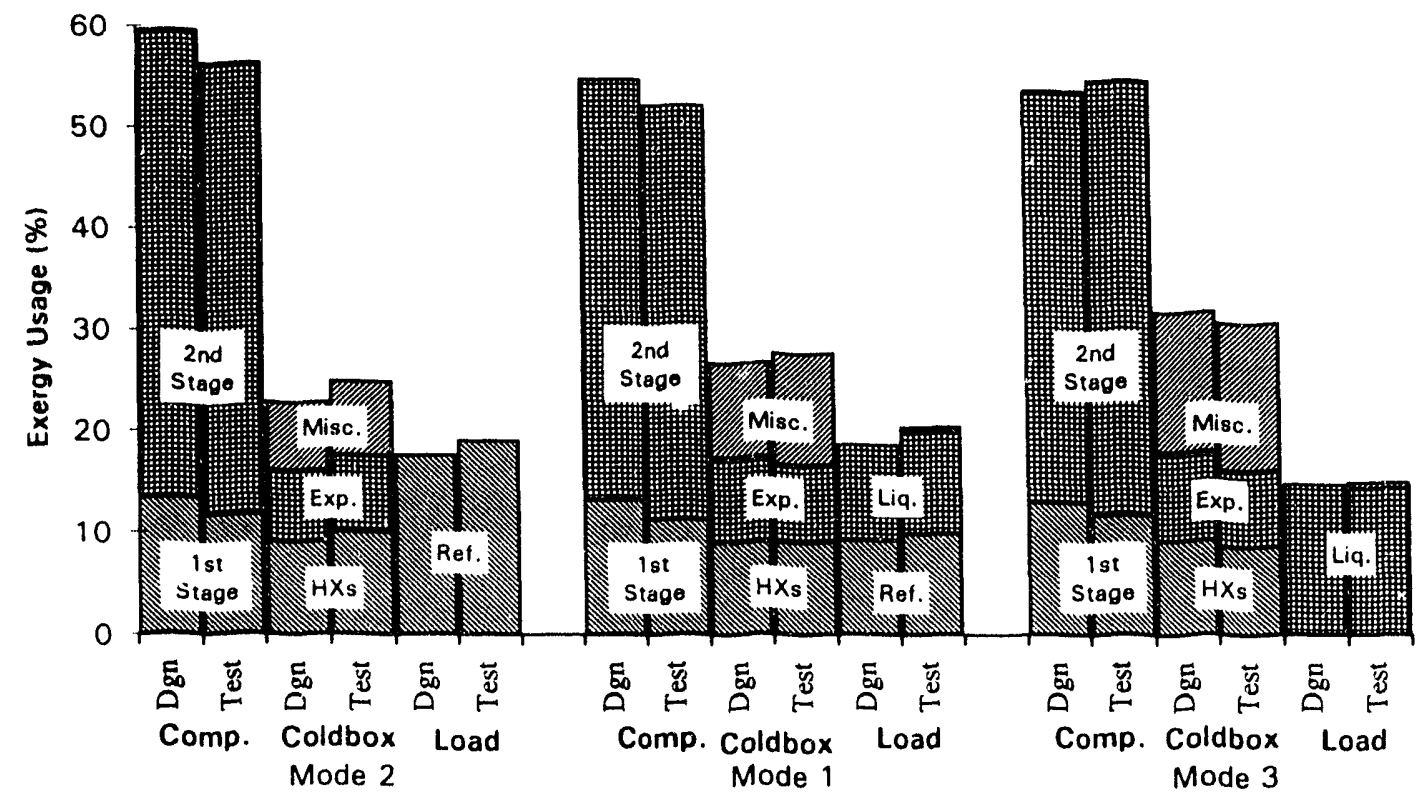

Figure 6. Summary of the exergy analysis. 
To enhance the system efficiency, improvements could be made to the second-stage compression process either by designing the system with reduced pressure ratio for the second stage (the increased compressor efficiency would more than compensate for the increased coldbox losses) or by using a different type of compressor. In summary, the exergy analysis comparison of the manufacturer's design with the actual test for the three modes of operation provides a clear insight into the component and system losses and behavior.

\section{REFERENCES}

1. U. Wagner and W. Keyer, "Process design features of the SSC MTL cryogenic system," in Supercollider 3: Proceedings of the 3rd International Symposium on the Super Collider, Atlanta, GA, March 1991, New York: Plenum Press, 1992.

2. T. Kobel and R. Than, "Initial operation and performance test results of the ASST cryogenic system," to be published in Supercollider 5: Proceedings of the Sth International Symposium on the Super Collider, San Francisco, CA, May 1993, New York: Plenum Press.

3. C. Trepp, "Refrigeration systems for the temperatures below $25 \mathrm{~K}$ with turboexpanders," in Advances in Cryogenic Engineering, Vol. 7, New York: Plenum Press, 1962, p. 25 i.

4. B. Ziegler, "Second law analysis of the helium refrigerators for the HERA proton magnet ring," in Advances in Cryogenic Engineering, Vol. 31, New York: Plenum Press, 1985, p. 693. 


\section{$=\|\|, \quad\|, \quad\|$}
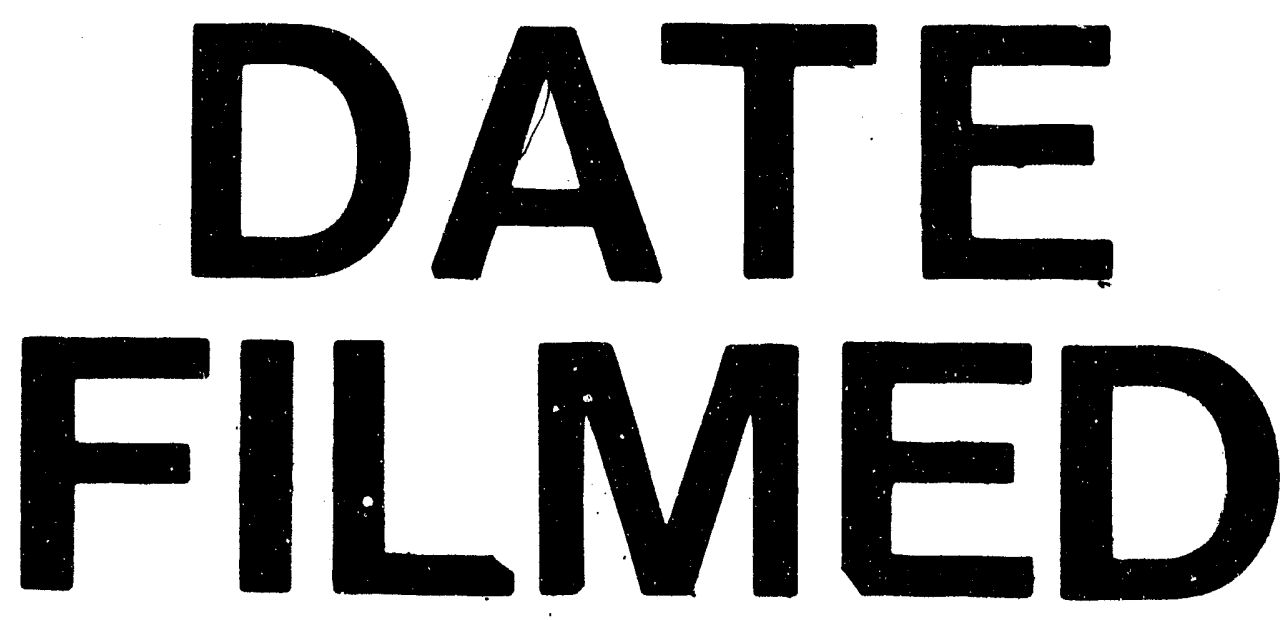

$10 / 18 / 93$ 
